\title{
An exegesis of the parable of the Good Samaritan (Lk 10:25-35) and its relevance to the challenges caused by COVID-19
}

\begin{tabular}{|c|c|}
\hline \multicolumn{2}{|c|}{$\begin{array}{l}\text { Authors: } \\
\text { Philemon M. Chamburuka } \\
\text { Ishanesu S. Gusha }\end{array}$} \\
\hline \multicolumn{2}{|c|}{$\begin{array}{l}\text { Affiliations: } \\
{ }^{1} \text { Department of Religious } \\
\text { Studies, Classics, and } \\
\text { Philosophy, Faculty of Arts, } \\
\text { University of Zimbabwe, } \\
\text { Harare, Zimbabwe }\end{array}$} \\
\hline \multicolumn{2}{|c|}{$\begin{array}{l}\text { ²Department of New } \\
\text { Testament and Related } \\
\text { Literature, Faculty of } \\
\text { Theology and Religion, } \\
\text { University of Pretoria, } \\
\text { South Africa }\end{array}$} \\
\hline \multicolumn{2}{|c|}{$\begin{array}{l}\text { Research Project Registration: } \\
\text { Project Leader: E. van Eck } \\
\text { Project Number: } 2400030\end{array}$} \\
\hline \multicolumn{2}{|c|}{$\begin{array}{l}\text { Description: } \\
\text { Both authors are participating } \\
\text { in the research project 'The } \\
\text { Parables of Jesus', directed by } \\
\text { Prof. Dr Ernest van Eck, } \\
\text { Department of New Testament } \\
\text { and Related Literature, Faculty } \\
\text { of Theology and Religion, } \\
\text { University of Pretoria. }\end{array}$} \\
\hline \multicolumn{2}{|c|}{$\begin{array}{l}\text { Corresponding author: } \\
\text { Ishanesu S. Gusha, } \\
\text { ishegusha2@gmail.com }\end{array}$} \\
\hline \multicolumn{2}{|c|}{$\begin{array}{l}\text { Dates: } \\
\text { Received: } 08 \text { May } 2020 \\
\text { Accepted: } 04 \text { Aug. } 2020 \\
\text { Published: } 12 \text { Oct. } 2020\end{array}$} \\
\hline \multicolumn{2}{|c|}{$\begin{array}{l}\text { How to cite this article: } \\
\text { Chamburuka, P.M. \& } \\
\text { Gusha, I.S., 2020, 'An exegesis } \\
\text { of the parable of the Good } \\
\text { Samaritan (Lk 10:25-35) } \\
\text { and its relevance to the } \\
\text { challenges caused by } \\
\text { COVID-19', HTS Teologiese } \\
\text { Studies/Theological Studies } \\
76(1) \text {, a6096. https://doi. } \\
\text { org/10.4102/hts.v76i1.6096 }\end{array}$} \\
\hline \multirow[b]{2}{*}{ 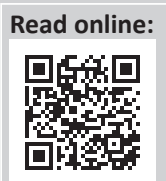 } & \\
\hline & $\begin{array}{l}\text { Scan this } Q R \\
\text { code with your } \\
\text { smart phone or } \\
\text { mobile device } \\
\text { to read online. }\end{array}$ \\
\hline
\end{tabular}

The article is on the exegesis of the parable of the Good Samaritan (Lk 10:25-35) and its relevance to the challenges that are being posed by COVID-19. Through the historicalcritical approach, the article has concluded that the parable is relevant in troubleshooting the challenges that are caused by COVID-19, such as discrimination, stigma, hate and stereotypes. The article sees COVID-19 as teaching humanity the important lesson that no one can live in isolation, however powerful or economically strong they are. Therefore, there is a need to take the opportunity of being a neighbour. Neighbourhood is understood as offering services to those in need and COVID-19 has presented a chance to the entire world to help someone with needs. A need-based world requires neighbours and this makes the parable relevant.

Contribution: This article is a reflection of the challenges that are currently faced by people in response to the COVID-19 pandemic. It is within the scope of this theological journal that issues of identity, relationships, and theological reflection should be addressed, hence the article fits well within this scope.

Keywords: COVID-19; Samaritan; Neighbour; Parable; Jesus; Lawyer; Priest; Levite; Robbers; Jericho; Jerusalem.

\section{Introduction}

Jesus was one of the greatest teachers in the ancient world. His use of the parables to put forward his message is especially notable. Barclay argues that 'it remains true that the stories Jesus told are the best known stories in the world' (Barclay 1970:9). Stiller concurs with Barclay in that 'the New Testament parables of Jesus are unique, without parallel' (Stiller 2004:9). Parables were central in the teachings of Jesus as Stein testifies that 'it is estimated that over one third of the teachings of Jesus found in the synoptic gospels are found in parables' (Stein 1981:15). This article seeks to discuss the relevance of the parable of the Good Samaritan in the context of the challenges that are being posed by the COVID 19 pandemic. The article begins by interpreting the parable, then discussing COVID 19 and finally appropriating the parable to the context of COVID 19.

\section{The historical-critical method}

David R. Law argues that the historical-critical method is 'a generic term given to a cluster of related approaches which all focus in some way on the historical character of the bible' (Law 2012:1). There are many methods that fall under the historical-critical method, varying from synchronic to diachronic methods. Keegan (1985:24) asserts that this method is a composite method encompassing such distinct methods as literary, source, form, redaction and textual criticism. Krentz (1975:27) defines the method as an approach to the study of materials from your past, which attempts to place them in their original historical contexts. Furthermore, Hayes and Holladay (1987:46) regard historical-critical method as based on the assumption that a text is historical in at least two senses: as relating to history as well as having its own history. The historical-critical method will be used to discuss the historical background of the parable which includes the geographical and cultural setting of Jericho and Jerusalem as well as the history of the relationships between the Jews and Samaritans.

Copyright: (C) 2020. The Authors. Licensee: AOSIS. This work is licensed under the Creative Commons Attribution License. Note: Special Collection entitled COVID-19 from a Theological Perspective, sub-edited by Jerry Pillay (UP). 


\section{Brief background to parables}

A brief overview of the parables in general is given before interpreting the Luke 10:25-35. When we were at school, we were taught that a 'parable' is a story with a deeper meaning or that it is an earthly story with a heavenly meaning. Yes, the definitions resemble some truths with the parables of Jesus, but that is partial truth as parables are deeper than that. So, what is a parable? This article intends to offer a working definition for this article and does not wish to engage in a lengthy debate or analysis on the various definitions of parables. The major reason for this approach is that this area has been exhausted over centuries and therefore we do not intend to reinvent the wheel. The English word 'parable' is a translation of the Greek word $\pi \alpha \rho \alpha \beta o \lambda \eta$. Scott defines the word $\pi \alpha \rho \alpha \beta o \lambda \eta$ as 'to set beside, to throw beside' (Scott 1989:19). It is a compound word made up of the Greek preposition ' $\pi \alpha \rho \alpha^{\prime}$, meaning 'from beside, by the side of, by, beside', and the noun ' $\beta 0 \lambda \eta$ ', meaning 'a casting, to throw'. Scott further argues that 'the word $\pi \alpha \rho \alpha \beta 0 \lambda \eta$ functions as a comparative term, indicating similarity or parallelism' (Scott 1989:19). It was from this etymology that many definitions were proffered, but significantly innovative is the aspect that the central message of the parables of Jesus was related to the Kingdom of God.

\section{Historical Context of Luke 10:25-35}

An analysis of the historical context of the parable helps us interpret it within its context rather than imposing our cotemporary context. In exegesis, we draw the meaning out of the text rather than putting the meaning in the text. The location of the parable is the road between Jerusalem and Jericho. Jerusalem was known as the city of worship with its magnificent temple, while Jericho was the residence for many people including priests and Levites. Therefore, it was expected that priests and Levites would travel regularly to Jerusalem to perform their temple duties. According to Stiller, the road was notorious for its robberies and became more dangerous when Herod laid off forty thousand construction workers, leaving plenty of unemployed, some of whom turned thievery' (Stiller 2004:70). The distance between Jericho and Jerusalem was 17 miles and the road cut across the desert and rocky hill country. This made the road a great hideout for robbers. Kendall (2011:186) stresses that it was a treacherous journey, and it still is not an easy journey today, even with a fairly good road. You still see Bedouins all over the area, and you wouldn't want to travel that way alone. Stiller therefore concludes that 'the robbery of a lone strange going down the road does not pose a surprise to the hearer' (Stiller 2004:194). Even Josephus remarked that 'when the Essenes travelled it, they carried arms to protect themselves from robbers' (Josephus n.d.). This illustrates the place was so dangerous that pious people like the Essenes had to take measures to protect themselves.

Other important characters worthy of discussion in the parable are the priest, the Levite and the Samaritan. The first character to pass by the half-dead victim was the priest.
He might have been returning after performing temple duties at Jerusalem. Priests were members of the tribe of Levi. The parable is silent on the reasons why the priest had to pass by the other side of the road. These gaps are filled either by reader's response or by narrative's critics. The first possible reason as proffered by Scott was 'fear of robbers, they may still be lingering around to attack yet once more' (Scott 1989:195). The second and most commonly held reason was concerns for purity. The dilemma before the priest was whether the man was dead or not. Leviticus 21:1-2 prohibits the priest from being defiled by a corpse through contact. They were only allowed to be in contact with the bodies of their nearest kin - mother, father, son, daughter, brother and virgin sister. Therefore, the priest had to play it safe because defilement had severe consequences for him and his family. According to Stiller, 'if the priest became unclean, he must return to Jerusalem, stand by the Eastern gate with the unclean, and go through the process of purification' (Stiller 2004:82). Scott (1989) further argues that:

[T] his ritual would not only take time, but it would result in the loss of wages. He would have to buy and offer a heifer, which would take up most of a week and be of significant cost to him, his family, and his household. (p. 195)

Therefore, the actions of the priest should be holistically understood in terms of the three spheres - spiritual, economic and social.

The next person to pass by was the Levite. Again, these were the descendants of the house of Levi and were part of the priestly community. Their role was to help or assist the priest in preparing the animals, grain and birds for sacrifice. According to Numbers 18:3, 'they could not take part in the offering itself'. They were also affected by purity laws as they also worked in the temple.

The third and surprising character was the Samaritan. Samaritans were viewed as half-Jews and they were excluded by the Jews from the covenant promises. Crossan (2012:61) contends that the tension started when Israel split into northern and southern kingdoms in the late 900s BCE. It intensified when the Assyrian Empire captured the northern kingdom in the late 700s BCE and the Babylonian Empire captured the southern kingdom in the early 500s BCE. It was an estrangement between descendants of the same ancestors, but by the first century it had hardened into ethnic, political and religious animosity within the land of Israel (Crossan 2012:69). Josephus writes that hostility was fuelled when the Samaritans desecrated the Jerusalem temple by scattering bones in it on one Passover night (Josephus n.d.). One would not therefore expect a Jewish rabbi (Jesus) to give a positive picture of a Samaritan. This was therefore a bombshell to the audience.

\section{Contextual analysis}

The positioning of the parable is important in interpreting it. The parable is positioned within what is called the travel narrative in which Jesus sets his focus towards Jerusalem 
(Lk 9:51). This is the trip that will finally end with his triumphal entry and crucifixion. In Luke 9:51-56, Jesus sends his disciples into the Samaritan region and the response was negative as the disciples were not allowed entry. They were angry and wanted Jesus to call fire upon them. Stiller argues that 'Jesus' response by rebuking the disciples help condition our feeling about Samaritans' (Stiller 2004:70).

\section{Formal analysis}

Here, we are examining how the parable story flows from the introduction to the conclusion. How is the plot of the text? The Lukan account places the parable in the context of the debate between a lawyer and Jesus over inheriting eternal life. Stiller argues that 'within the Jewish community, public debate was the order of the day, well known rabbis often engaged in public debates' (Stiller 2004:80). The lawyer's question is paralleled to that of the rich young ruler in Luke 18:18. Luke 10:25-37 is therefore divided into two parts.

\section{Part 1 (Lk 10:25-28):}

1. Lawyer's question-what must I do to inherit eternal life?

2. Jesus' counter-questions- What is written in the Law? How do you read it?

3. Lawyer's answer- citing Deuteronomy 6: 4 and Leviticus 19:18.

4. Jesus' response and command- You have answered correctly. Do this and you will live.

The lawyer has created a new text by synthesising two texts. Stiller argues that 'merging two texts was common among Jewish rabbis' (Stiller 2004:80).

Part 2 (Lk 10:29-37):

1. Lawyer- And who is my neighbour?

2. Jesus-telling the parable of the Good Samaritan

3. Jesus- Which of these three do you think was a neighbour to the man who fell into the hands of robbers?

4. Lawyer- he one who had mercy on him

5. Jesus- Go and do likewise.

Blomberg concludes that 'Levite and priest sharing one role as the negative model and the Samaritan providing the shocking counter example' (Blomberg 2012:301). There have been debates on the unity and integrity of these two parts and the majority of scholars view them as unrelated. However, that debate does not concern this article.

\section{Detailed analysis}

This is the area where we interpret the parable in detail as we attempt to establish its message. Scott is of the view that 'the parable calls for the barriers that separate the two; the Jewish fictional audience has to imagine the Samaritan as neighbour' (Scott 1989:190). The parable is challenging the boundaries that we set amongst ourselves as humanity. These are the identity boundaries that separate humanity along ethnic, racial, tribal, regional and national levels. As a surprise element of reversal of expectations, the Jews see the Samaritans as neighbours and not enemies. By telling this parable, Jesus is breaking down barriers that separate humanity. According to Wailes, 'the parable demonstrates four things; the ruin of the human race, the devil's persecution, the inadequacy of the law and Christ's mercy' (Wailes 1987:210).

The other view is that this parable should not be understood in the context of ethnic or racial barriers but in the context of humanity. Stiller (2004) argues that:

$[B]$ ecause his identity was stripped from him, those passing by knew nothing of his social or economic status nor his place of origin, which they would have known by his clothes. (p. 82)

Blomberg concurs that 'Jewish and Samaritan men alike were circumcised, so for all we know the Samaritan could have thought that the half-dead man was one of his own countrymen' (Blomberg 2012:300; Jeremias 1972:203; Zimmerman 2015:299). Therefore, the subject of distinction with one's enemy should not be emphasised and the focus of the parable should rather be on the call to show love and compassion universally. The counter argument, however, is that the majority users of this road were likely Jews and not Samaritans. Therefore, to assume that the half-dead man was a Samaritan or other gentile is highly unlikely. Even considering the fact that the audience was most likely Jewish, the parable still plays the same role of breaking barriers that separate humanity. The Samaritan is therefore synonymous with a humanitarian. As Snodgrass (2008) points out:

$[A] 11$ three travelers see the man, but for the priest and Levite, seeing is the impetus for caution and self-protection, while for the Samaritan seeing is the source of compassion which motivates his helping. (p. 344)

We concur with Donahue that the priest and the Levite are caught in a moral dilemma - to observe the Torah on cleanness or the Torah on love the neighbour (Donahue 1998:131). As we conclude on the detailed analysis of the parable, we would like to end with the summary of Blomberg (2012) that three lessons can be drawn from the parable:

1. From the example of the priest and Levite comes the principle that religious status or legalistic casuistry does not excuse loveliness.

2. From the Samaritan, one learns that one must show compassion to those in dire need regardless of the religious or ethnic barriers that divide people.

3. From the man in the ditch emerges the lesson that even one's enemy is one's neighbour. (p. 302)

These are the lessons that help us to establish the relevance of the parable to the challenges that are being poised by COVID-19.

\section{The historical background of COVID-19}

The acronym COVID-19 is broken as follows: CO - Corona; VI - virus; D - disease; and 19 - the year the first cases of 
the people affected by the disease were discovered in China. According to the ECDC report (2020:1), 'COVID-19 emerged in December 2019 in Wuhan, the capital of Hubei province, China'. The virus was previously unknown. Demertzis et al. (2020) argue that:

A week after the Chinese alert, it was announced that this virus was a new variety belonging to the coronavirus family, which includes the common cold and SARS, the severe acute respiratory syndrome that killed more than 770 people worldwide in 2002-2003. (p. 2)

The rest of the world did not take serious caution when COVID-19 was discovered in China because the common thinking was that it was a Chinese problem like the past case of SARS. The virus continued to spread and on 30 January 2020, the World Health Organization (hereinafter referred to as WHO) declared that the outbreak now constituted a public health emergency of international concern. The world was now beginning to feel the heat of the virus. The next epicentre of the virus outside China was Iran, then Italy, Spain, England, the United States of America, Ecuador, and then isolated cases in Africa. It had now ceased to be a problem of China alone but developed into an emerging global challenge. Wuhan became the epicentre of the virus. On 11 March 2020, the WHO declared COVID-19 as pandemic. It still remains a mystery as to how the virus was transmitted to human beings at the start of the event.

Scientists from China as well as other countries are busy researching the animal source of this virus. Hu et al. (2015) argue that:

Bats, with extensive geographical distribution and capability of flight, constitute the second largest group of mammalian species and have, been documented as natural hosts of a large number of diverse viruses such as lyssaviruses, paramyxoviruses and filoviruses. In the past decade, numerous novel coronaviruses have been discovered in a wide variety of bat species throughout Asia, Europe, Africa and America. (p. 1)

It is fascinating that concerns about such viruses date back to some decades ago and one wonders how humanity was caught unaware when there had been researches in the past. Bats remain the possible transmitters of this novel virus although no conclusions have been reached so far. The current discourse is that the transmission of the virus from bats to humans should have been as a result of eating them. According to the WHO report (2020:2), 'bats are rare in markets in China but are hunted and sold directly to restaurants for food'. Therefore, it is probable that the virus was transmitted through those restaurants.

There have been some conspiracy theories on the possible origins of the disease and some blame the latest communication technologies, such as $5 \mathrm{G}$. Some see it as biological warfare between the world's two greatest economies - China and the United States of America. Christians attach some apocalyptic meaning to the outbreak of the pandemic. The fact remains that the reasons behind the outbreak of the virus remain unclear.

\section{Health facts about COVID-19}

Here, we need to highlight some facts about COVID-19 as they will help us to interpret people's behaviours towards it. According to the International Society for Dermatologic Surgery (ISDS) 20 March 2020 report, 'the mean age of patients dying from COVID-19 infection was 78.5 years' (ISDS 2020:2). These are facts based on research in Italy. Many of these people dying from COVID-19 infections have pre-existing medical conditions, such as ischemic heart disease, atrial fibrillation, stroke, hypertension, diabetes, dementia, Chronic Obstructive Pulmonary Disease (COPD), active cancer, chronic liver disease and chronic renal failure. Upon admission at the hospital, patients infected with COVID-19 would have the following symptoms: fever, cough and difficulty in breathing. The virus is said to be spread through respiratory droplets that are produced when an infected person coughs or sneezes and through people being in close contact. How can people avoid being infected by the virus? The WHO (2020) gives us the following precautionary guidance:

1. Avoid close contact with people suffering from acute respiratory infections.

2. Wash your hands frequently with soap and water, especially after direct contact with ill people or their environment.

3. Avoid unprotected contact with farm and wild animals.

4. People with symptoms of acute respiratory infection should practice cough etiquette (maintain distance, cover coughs and sneezes with disposable tissues or clothing and wash hands).

5. Avoid touching your eyes, nose or mouth with unwashed hands.

6. Stay home while you are sick and avoid close contact with others. (p. 7)

These six precautions help in minimising the spread of the virus, but they impact on people's religious and cultural customs like handshakes, hugging or kissing when greeting one another.

\section{The Social, economic and political impact of COVID-19 on the globe}

Devakumar et al. (2020) argue that:

Outbreaks create fear, and fear is a key ingredient for racism and xenophobia to thrive. The COVID-19 pandemic has uncovered social and political features within communities, with racialized and discriminatory responses to fear, disproportionately affecting marginalized groups. (p. 1194)

Instead of uniting against the deadly pandemic, nations and races are busy venting anger on one another. Political leaders have taken this as an opportunity to attack one another. The president of the United States of America, 
Donald Trump, is on record calling the virus 'Wuhan virus', 'Chinese virus' or 'Asian virus'. It is discriminatory to attach locations or ethnicity to a disease. This is a perpetuation of the economic or trade war that has been going on between these two nations. The former deputy prime minister of Italy, Matteo Salvini, 'wrongly linked COVID-19 to African asylum seekers, calling for border closures' (Devakumar et al. 2020). One should realise that the issue here has nothing to do with the spread of COVID-19. Rather, COVID-19 has become a platform to deliver anti-migration rhetoric aimed at African immigrants in Italy. When Salvini made these remarks, Africa was not even an epicentre of the virus. Also, why not address such sentiments against migrants from China or Iran? Iran is also blaming its enemy, the United States of America, for failure to combat COVID-19. Sepehrrad (2020) argues that:

[A] lid on the true number of COVID-19 victims in Iran to prevent another nationwide uprising, it is blaming US sanctions and claiming these measures hinder Tehran's access to medical supplies and equipment. (p. 3)

It is true that sanctions have economic bearing especially when fighting a pandemic, but Iran cannot justify expelling Doctors Without Borders. It cannot justify concealing the true figures of people dying from COVID-19. One can therefore conclude that these are political battles where everyone is blaming their enemy. In the Zimbabwean context, Minister Oppah Muchinguri celebrated the death of people in America and Europe from COVID-19 on the grounds that they were being punished by God for imposing sanctions on Zimbabwe. In France, two medical scientists, Dr Cammille Locht and Dr Jean-Paul Mira, publicly proposed the testing of the new COVID drugs in Africa. The proposal was shot down by the WHO director general Dr Tedros Adhanom as 'racist and a hangover of colonial mentality' (Chipunza 2020). The WHO boss pointed out that standard and acceptable procedures were to be followed regardless of location and race. Responses by the WHO angered Trump who withdrew the United States funding of WHO. The national church in the United States of America and World Council of Churches labelled Trump's action as 'dangerous, immoral and wrong' (WCC 2020). COVID-19 has become a battlefield for politicians and a cue for past tensions.

COVID-19 has resulted in stigma against some people. For example, there is discrimination against Chinese people in public spaces, hence the tag, 'Chinese virus'. Rather than being an equaliser among nations because of its ability to affect anyone, COVID-19 has created more barriers among nations and individuals. The pandemic has provoked social stigma and discriminatory behaviours. The stigma is anchored on certain factors (United Nations Children's Fund, World Health Organization \& International Federation of Red Cross and Red Crescent Societies [UNICEF, WHO \& IFRC] 2020):

1. It is a new disease and with many unknown facts.
2. People are normally afraid of the unknown.

3. In such cases then, blame is shifted on the other. (p. 1)

In the context of stigma, social cohesion becomes difficult and discrimination broadens.

Devakumar et al. conclude that 'health protection relies not only on well-functioning health systems with universal coverage, but also on social inclusion, justice and solidarity' (Devakumar et al. 2020). The outstanding question then is, 'how would the parable of the Good Samaritan become relevant in the context of COVID-19 that has caused stigma, discrimination, hate, stereotypes and marginalisation of other people?'

\section{Relevance of the parable of the Good Samaritan and challenges posed by COVID-19}

The previous discussion on COVID-19 has identified the following as challenges posed by the pandemic: discrimination (ethnicity, racism and regionalism), hate speech, social stigma, xenophobia and stereotypes. Therefore, the relevance of the parable is in troubleshooting the above challenges.

\section{Discrimination}

In the setting of the parable, the two characters, the lawyer and the Samaritan, are inheritors of the discrimination that dates back to previous generations. The lawyer represented Jews who always discriminate against the Samaritans as unclean people of mixed blood. The separation led to the bad blood between the two to the extent that the Samaritan woman was not prepared to give Jesus water at the well simply because their ethnicity was different. Jesus by telling the parable of the Good Samaritan was simply asking the lawyer (Jew) to consider the Samaritan as the neighbour. In the parable, we see an attempt to break racial or ethnic barriers. Racial and ethnic discrimination is exacerbated by social stigma and stereotypes. This parable is very relevant in the world characterised by divisions based on racial and ethnic identities. An understanding of the parable helps people refrain from derogatory terms such as 'Wuhan, Chinese or Asian virus'. An understanding of the parable helps in avoiding racial statements such as 'we should use Africans as Guinea pigs in testing new drugs or that COVID-19 is being brought to Italy by African migrants'. The parable helps in troubleshooting fear of the pandemic that is now translating into xenophobic attacks. It is a relevant parable in destroying ethnic, racial and regional boundaries that are separating humanity. The Chinese should be encouraged to avoid discrimination against African immigrants under the disguise that they are responsible for reinfections in Wuhan and other cities in China. We commend the stance taken by African Union and African embassies in China to engage the Chinese government on need to treat Africans with dignity and to observe human rights of African immigrants. As alluded above, the parable of the Good Samaritan demands that we destroy any forms of stigmatisation globally. 


\section{Compassion to help those in need}

Discrimination affects humanitarian work or acts of charity. Humanitarian work begins with recognising that those in need are humans of equal dignity. In discrimination, there is an aspect of seeing other people as objects and not humans. Health workers around the globe should therefore be saluted for seeing the opportunity to serve at the expense of personal safety. The Good Samaritan did not think of personal protection at the expense of helping the wounded man. By proposing to test drugs in Africa, one is simply insinuating that Africans are not humans but rats to be used for laboratory tests. In the parable, Jesus teaches that to be a neighbour means to save the one in need. COVID-19 has posed challenges of material, economic, moral and spiritual needs. Those with wealth are invited to provide financial or material assistance. In the context of the parable, a powerful and wealthy country like the United States of America should be urged not to withdraw financial support to the world's largest heath body. Those without financial or material muscle like Zimbabwe should give moral or spiritual support to those affected by the virus instead of celebrating their demise. For instance, Ms Oppah Muchinguri, Zimbabwe's defence minister, called the coronavirus pandemic a 'punishment' for the United States of America and Europe for imposing sanctions against members of the ruling regime over human rights abuses. These sentiments are regrettable indeed, worse if they are coming from a government official. Therefore, the outbreak of the pandemic should whet the appetite of assisting one another instead of fuelling political grudges. Through the parable, the world is being asked to take the character of the Good Samaritan instead of the priest and Levite. Political, economic, social and religious barriers cannot be excuses for not being a neighbour.

\section{One's enemy is one's neighbour}

The victim of the robbers had two great lessons - never travel alone and one's perceived enemy is one's neighbour. The biggest lesson that COVID-19 has taught us is that we will never be all sufficient, regardless of our economic and political strength. Even the powerful nations have succumbed to the pandemic regardless of their political and economic muscle. Even those that have built walls on their borders could not prevent the pandemic from entering their countries. We now perceive the world as a global village and therefore we cannot live in isolation. Social inclusion is therefore an important lesson to be drawn from the parable and it is an important aspect in fighting the pandemic as nations. The audience, the lawyer and the wounded man had to learn that the one who was perceived by history as an enemy was in fact a neighbour. Theologically, the parable rules out any possibility of creating enemies. This should be the greatest lesson for the world especially in these days of COVID-19. The entire world is in need and therefore everyone is a potential neighbour.

\section{Conclusion}

In conclusion, the relevance of the parable of the Good Samaritan in the context of challenges posed by COVID-19 cannot be undermined. The discussion on the parable has shown that it can troubleshoot many challenges that the world is currently facing. It is a parable that has the potential of transforming the world from polarisation to love and cohesion. The parable is important in eliminating stigma and breaking social barriers in various communities.

\section{Acknowledgements Competing interests}

The authors declare that they have no financial or personal relationships that may have inappropriately influenced them in writing this research article.

\section{Authors' contributions}

P.M.C. and I.S.G. contributed to the design and implementation of the research, to the analysis of the results and to the writing of the research article.

\section{Ethical considerations}

This article followed all ethical standards for research without direct contact with human or animal subjects.

\section{Funding information}

This research received no specific grant from any funding agency in the public, commercial or not-for-profit sectors.

\section{Data availability statement}

Data sharing is not applicable to this article as no new data were created or analysed in this study.

\section{Disclaimer}

The views and opinions expressed in this article are those of the authors and do not necessarily reflect the official policy or position of any affiliated agency of the authors.

\section{References}

Barclay, W., 1970, And Jesus said. A handbook on the parables of Jesus, Westminster Press, Philadelphia, PA.

Blomberg, C.L., 2012, Interpreting the parables, InterVarsity Press, Leicester.

Chipunza, P., 2020, 'WHO raps coronavirus drug trials in Africa', The Herald, viewed 18 April 2020, from https://www.herald.co.zw/who-raps-coronavirus-drug-trials-inafrica/.

Crossan, J.L., 2012, The power of parable: How fiction by Jesus became fiction about Jesus, Harper One, New York, NY.

Demertzis, M., Sapir, A., Tagliapietra, S. \& Wolf, G.B., 2020 'An effective economic response to the coronavirus in Europe', Bruegel, viewed 18 April 2020, from https://www.bruegel.org/2020/03/economic-response-coronavirus/.

Devakumar, D, Shannon, D. Bhopal, G. \& Abubakar, I, 2020, 'Racism and discrimination in COVID-19 responses', The Lancet, viewed 18 April 2020, from https://www.thelancet.com/journals/lancet/article/PIIS0140-6736(20)30792-3/ fulltext.

Donahue, J.R., 1998, The gospel in parable, Fortress Press, Philadelphia, PA.

European Centre for Disease Prevention and Control (ECDC), 2020, 'Outbreak of nove coronavirus disease 2019 (COVID-19): increased transmission globally -fifth update', ECDC report, viewed 17 April 2020, from https://www.ecdc.europa.eu/ sites/default/files/documents/RRA-outbreak-novel-coronavirus-disease-2019increase-transmission-globally-COVID-19.pdf.

Hayes, J.H. \& Holladay, C.R., 1987, Biblical exegesis, John Knox Press, Atlanta, GA 
Hu, B., Ge, X., Wang, L-F. \& Shi, Z., 2015, 'Bat origin of human coronaviruses', Virology Journal 12(221), 1-10. https://virologyj.biomedcentral.com/track/pdf/10.1186/ s12985-015-0422-1

International Society for Dermatologic Surgery (ISDS), 2020, Characteristics of COVID-19 patients dying in Italy, Report 20 March 2020, viewed 01 April 2020, from https://www.epicentro.iss.it/coronavirus/bollettino/Report-COVID-2019_ 20 marzo_eng.pdf.

Jeremias, J., 1972, The parables of Jesus, SCM Press, London.

Josephus, F., n.d., The antiquities of the Jews, transl. W. Whiston, viewed 12 March 2020, from https://www.fulltextarchive.com/page/The-Antiquities-of-the-Jews/.

Keegan, T.J., 1985, Interpreting the Bible, Paulist, New York, NY.

Kendall, R.T., 2011, The parables of Jesus: A guide to understanding and applying the stories Jesus told, Baker Publishing, Grand Rapids, MI.

Krentz, E., 1975, The historical-critical method, Fortress, Philadelphia, PA.

Law, D.R., 2012, The historical-critical method: A guide for the perplexed, T\&T Clark International, London.

Sepehrrad, R., 2020, 'Opinion - Iran's end game beyond coronavirus', e-Internationa Relations, viewed 18 April 2020, from https://www.e-ir.info/2020/04/07/opinionirans-end-game-beyond-coronavirus/.

Scott, B.B., 1989, Hear then the parables: A commentary on the parables of Jesus, Fortress Press, Minneapolis, MN.
Snodgrass, K., 2008, Stories with intent: A comprehensive guide to the parables of Jesus, William B. Eerdmans, Grand Rapids, MI.

Stein, R.H.,1981, An introduction to the parables of Jesus, The Westminster Press, Philadelphia, PA.

Stiller, B.C., 2004, Preaching parables to postmoderns, Fortress Press, Minneapolis, MN.

United Nations Children's Fund, World Health Organization \& International Federation of Red Cross and Red Crescent Societies, 2020, 'Interim guidance for COVID-19 prevention and control in schools', United Nations Children's Fund, New York, NY.

Wailes, S.L., 1987, Medieval allegories of Jesus' parables, University of California Press, Los Angeles, CA.

World Council of Churches, 2020, 'US church leaders, WCC dismayed and urge reversal of Trump's suspension of WHO funding', oikoumene, viewed 20 April 2020, from https://www.oikoumene.org/en/press-centre/news/us-church-leaders-wccdismayed-and-urge-reversal-of-trumps-suspension-of-who-funding-1.

World Health organization (WHO), 2020, 'Novel Coronavirus(2019-nCoV) Situation Report-22' World Health Organization, viewed 18 April 2002, from https://www. who.int/docs/default-source/coronaviruse/situation-reports/20200211-sitrep22-ncov.pdf?sfvrsn=fb6d49b1_2.

Zimmerman, R., 2015, Puzzling the parables of Jesus: Methods and interpretation, Fortress Press, Minneapolis, MN. 